\title{
Rereading of The Sabbath Law (Exodus 20: 8-11) as A Response to Modern Slavery Issue
}

\author{
Yohanes Rahdianto Suprandono ${ }^{1{ }^{*}}$, Robert Setio ${ }^{2)}$ \\ 1) Kharisma Theological Seminary Bandung, Indonesia \\ 2) Duta Wacana Christian University, Yogyakarta, Indonesia \\ *) Correspondent author:yrsuprandono@gmail.com
}

Received: 12 March 2021/ Accepted: 11 September 2021/ Published: 20 October 2021

\begin{abstract}
This research was motivated by concerns about the problem of modern slavery. The author will interpret Exodus 20:8-11 on the Sabbath to respond to the issue of slavery. The method of interpretation that will be used is deconstruction and social criticism. The use of the social criticism method sees the text as a practice of discourse that is ideologically charged and has specific interests. The text is not neutral but rather is advocating. In the text itself, two social groups conflict with each other. The interpretation of the existing Sabbath is interpreted normatively, legalistically, ritualistically, sociologically, theologically and eschatologically. The results of reinterpreting the Sabbath using a deconstructive method show that the Sabbath has been abolished because every day is interpreted as a forced workday. Forced labour is driven by fear and worry. The Sabbath was forgotten for political and economic motives. The Sabbath was abolished because time was money, so people were traded and enslaved for the sake of making money. The reinterpretation of the Sabbath text with the method of social criticism finds the theological meaning of the Sabbath. The God of the Sabbath is described as the forerunner of the liberation of slavery throughout the ages. God's Sabbath-keeping people today have a liberation mission to help people who are victims of modern slavery.
\end{abstract}

Keywords: Sabbath, deconstruction, social critical, slavery, modern

\begin{abstract}
Abstrak
Penelitian ini dimotivasi oleh keprihatinan akan masalah perbudakan modern. Penulis akan menafsir Keluaran 20:8-1l tentang Sabat untuk merespon isu perbudakan. Metode penafsiran yang akan digunakan dekonstruksi dan kritik sosial. Penggunaan metode kritik sosial melihat teks sebagai sebuah praktik dari wacana yang bermuatan ideologis dan adanya kepentingan tertentu. Teks bersifat tidak netral, melainkan bersifat memberikan advokasi. Di dalam teks itu sendiri ada dua kelompok sosial yang saling berkonflik. Hasil penafsiran tentang
\end{abstract}


Sabat yang ada selama ini dimaknai secara normatif, legalistik, ritualistik, sosiologis, teologis dan eskatologis. Hasil penafsiran kembali tentang Sabat dengan metode dekonstruktif menunjukkan Sabat telah ditiadakan karena setiap hari dimaknai sebagai hari kerja yang dipaksakan. Kerja paksa digerakkan oleh ketakutan dan kekhawatiran. Sabat dilupakan karena motif politis dan ekonomis. Sabat ditiadakan karena waktu adalah uang, sehingga orangpun diperjualbelikan dan diperbudak demi meraup keuntungan akan uang. Penafsiran kembali dari teks Sabat dengan metode kritik sosial menemukan makna Sabat secara teologis. Allah atas Sabat digambarkan sebagai pelopor pembebasan perbudakan di sepanjang masa. Umat Tuhan yang menganut Sabat di masa kini memiliki misi pembebasan untuk menolong orang yang menjadi korban perbudakan modern.

Kata-kata kunci: Sabat, dekonstruksi, kritik sosial, perbudakan, modern.

\section{Introduction}

East Nusa Tenggara is a province that has many cases of human trafficking. In 2015, 468 people indicated that they were victims of human trafficking. The Eastern Indonesian Women's Network noted that from January 2014 to April 2017, there were 237 victims of human trafficking who were sent back with their bodies lifeless, either intact or not. Many of the victims of slavery are suspected of being buried secretly, and it is even suspected that their organs were illegally traded. ${ }^{1}$

Slavery in modern times is a real thing. Depriving someone of their freedom is a crime that violates human rights. ${ }^{2}$ The term slavery means that one person owns another human being. Humans are properties in a similar way to how lamps or cabinets are held. Commercial slavery is a business that still exists in some parts of the world. Over the centuries, it has been a form of inhuman and abusive treatment of one human being by another. ${ }^{3}$ Examples of forced labour, debt bondage (through labour contractors and crew agencies) and restricted movement are shared. Some

${ }^{1}$ Herman Arnolus Manoe, "Resensi: Menolak Diam-Gereja Menolak Perdagangan Orang," Gema Teologika: Jurnal Teologi Kontekstual dan Filsafat Keilahian 4, no. 1 (2019): 12l, https://doi.org/10.21460/gema.2019.41.425

2 The Global Slavery Index, "Executive Summary," Walk Free Foundation, 2018, https:/www.globalslaveryindex.org/2018/findings/executive-summary/

${ }^{3}$ Michael J. Palmiotto, "Introduction: Human trafficking-modern slavery," in Combating Human Trafficking a Multidisciplinary Approach, ed. by Michael J. Palmiotto (United states: CRC Press 2015). 
even constitute global trade prohibited under New Zealand law, but criminal charges have not been made. ${ }^{4}$

The biblical perspective on slavery is explained in the Old Testament. The Bible states that slavery is legal as a form of human relationship, which is expressly sanctioned by God's laws, not questioned by Jesus, and affirmed even regulated by the apostle Paul. ${ }^{5}$ There are two factors concerning the Bible that shape the nature of the United States debate on slavery. First, the Bible explores the ideology of slavery. It consists of writings by writers that fit their society's custom of embracing slavery as a legal practice. Religious debates about slavery usually concern what the Bible means and not human brutality itself. ${ }^{6}$

The relationship between the Sabbath and slavery in the Old Testament is an exciting topic to study. Issues related to modern slavery go beyond the biblical understanding of slavery. Blevins argues that the statement in Deuteronomy remembering Israel's deliverance from slavery in Egypt is superior and leads to a more helpful interpretation of the Sabbath commandment than the Exodus justification, which refers to God's actions in creation. ${ }^{7}$ Sabbath observance is essential because the Sabbath is an integral part of God's will to restore Imago Dei to fallen mankind. ${ }^{8}$

\section{Understanding the Social Context of the Problem of Modern Slavery}

Biblically, the problem of slavery is complicated because in Old Testament text has a double meaning. A slave is the formative result of the Hebrew verb עִכְ - 'eved' 'slave' or 'servant'. Servant does not only apply to

${ }^{4}$ C. Stringer, D. H. Whittaker, and G. Simmons, "New Zealand's turbulent waters: the use of forced labour in the fishing industry," Global Networks 16, no. 1, (2016): 3-24; K. L. Christ, K. K. Rao and R. L. Burritt, "Accounting for modern slavery: an analysis of Australian listed company disclosures," Accounting, Auditing \& Accountability Journal 32, no. 3 (2019): 836-865.

${ }^{5}$ John M. G. Barclay, "Am I not a Man and a brother? The Bible and the British Anti-Slavery Campaign," The Expository Times 119, no. 1 (2007): 3-14.

${ }^{6}$ Sylvester A. Johnson, "The Bible, Slavery, and the Problem of Authority," in Beyond Slavery. Black Religion/Woman Thought/Social Justice (New York: Palgrave Macmillan, 2010), 231-248, https://doi.org/10.1057/9780230113893_4

${ }^{7}$ Kent Blevins, "Observing Sabbath," Review and Expositor 113, no. 4 (2016): 478487.

${ }^{8}$ Mathilde Frey, "The Sabbath in the Pentateuch: An Exegetical and Theological Study," (Dissertations Ph.D., Andrew University Seventh-day Adventist Theological Seminary, 2011), https://digitalcommons.andrews.edu/dissertations/51 
people who belong to others in the sense of people enslaved to others. The עִ עֶרד (eved) means slave, servant, servant or servant which is used 803 times in the OT, which comes from the root word עָבָב - 'avad (verb form) which is used 289 times in the OT which means to work, serve, work earnestly. Therefore, it is only from the context that will determine the meaning of slave. Even from the same root word comes עִ עבדָה - 'avodah, which means; work, work, serve and worship. ${ }^{9}$ In the use of the words male slave (עֶכֶ) (אמה) (Exodus 21: 2; 21:7) and female slave Gentile slaves (Lev. 25:44). There are instances in the OT where the term slave ('eved) was used to designate a person as a servant of God (Exodus 32:13), the word slave to refer to the subject and official authority (Gen. 21:25; 40:20), to refer to self. himself in humility before his fellow humans (Gen. 33:5) and refers to oneself when speaking to God (Ex. 4:10). Indeed, the word עֶֶר - 'eved can also mean someone who belongs to another (Gen. 12:16; cf. Exodus 20:17). And the word 'eved is used as a noun to indicate being conquered. ${ }^{10}$

Over time, the meaning of slavery has shifted conceptually. In general, slavery is understood as a condition in which a person, family, or other institution is treated by another person as property, so that the person's freedom is taken away, then exploited for the benefit of a person or group of people, family, or institution that practices slavery. Slavery is an exploitative situation where a person cannot refuse or leave something, because of threats, violence, coercion, abuse of power, and fraud. This can include situations where a person is forced to work without pay due to debt, female workers who work long hours; Modern slavery also appears in the form of child abuse, such as trafficking of minors, forced marriage, domestic slavery, and prostitution practices. Modern slavery includes acts of violence that are felt by the victims. Taking away someone's freedom is a crime that violates human rights. ${ }^{11}$

In the last 50 years we have seen the world's population from 2 billion to 7 billion people. The number of people is so large, everyone is racing to get a job. And sometimes jobs in very bad conditions are still carried out because there is no other choice. The extreme poverty factor also causes a person to become ensnared into the practice of slavery. If a person does not have many options for earning a living, then whatever offers come their way will be taken. Corruption also fosters the practice

${ }^{9}$ Miles V. Van Pelt, Gary D. Pratico, The Vocabulary Guide to Biblical Hebrew (Grand Rapids, Michigan: Zondervan, 2003), 10, 118.

${ }^{10}$ G. H. Haas, "Slave, Slavery" in Dictionary Old Testament: Pentateuch, ed. T. Desmond Alexander, David W. Baker (Downers Grove, IL InterVarsity Press, 2003), 778-779.

${ }^{11}$ Slavery Today, "What is modern slavery," https://www.antislavery.org/slaverytoday/modern-slavery/ 
of slavery. Corruption makes the police and law enforcers reluctant to enforce the law, even though almost all countries make slavery a violation of the law. ${ }^{12}$ Modern slavery has been exposed as a new social order, therefore the author wants to discuss the Sabbath law of Exodus 20: 8-11 in relation to the issue of slavery. First of all, the text will be deconstructed and then used an approach to reconstruct the text using the social criticism method.

\section{Method}

Concern with the problem of modern slavery encourages the author to conduct research efforts on the text of Exodus 20: 8-11 which will be carried out with a postmodern Old Testament Theology approach. To achieve the objectives of the research, the writer will use methods that fit the postmodern atmosphere. The method of deconstructing the already established interpretation and reconstructing it is based on the sociological critique paradigm.

The postmodern Old Testament Theology approach with the deconstruction method of reading the text will be done by directing the storyline which is not as usual which is normative. The strategy of reading the text is carried out in the opposite way than in general, by emphasizing the opposite. This means acknowledging the current (original) truth and trying to read the text from another perspective. In this way, the Exodus text is highlighted from the perspective as a testimony from the narrator. The God in the Exodus who saved the Israelites from Egypt also assumed the same truth that the same God also destroyed and humiliated the Egyptians. Even so, the text itself does not allow us to think that far or allow us to know where it got there, because the text wants us to ignore that knowledge and focus on Israel's liberation. ${ }^{13}$

The deconstruction method aims to deconstruct meanings that are already considered fixed but do not care about human rights issues. ${ }^{14}$ Through the deconstruction approach, it recognizes that there is ambiguity and plurality of meanings in discourse. ${ }^{15}$ Deconstruction is a

12 The Global Slavery Index, "Executive Summary," Walk Free Foundation, 2018, https:/www.globalslaveryindex.org/2018/findings/executive-summary/

${ }^{13}$ David J. Clines, "Images of Yahweh: God in the Pentateukh," In Studies in Old

Testament Theology, ed. Robert L. Hubbart, Robert K. Johnston, Robert P. Meye (Dallas: Word Publishing, 1992), 77-93.

${ }^{14}$ Emanuel Gerrit Singgih, "Membaca Dan Menafsir Alkitab Di Indonesia," dalam Teologi Yang Membebaskan Dan Membebaskan Teologi," ed. Wahju S. Wibowo, Robert Setio (Yogyakarta: Fakultas Teologi UKDW, 2016), 117-118.

${ }^{15}$ Emanuel Gerrit Singgih, "Resensi: Sebuah Teologi Perjanjian Lama Postmodernis," Gema Teologika: Jurnal Teologi Kontekstual dan Filsafat Keilahian 1, no. 1 (2016): 117-118, https://doi.org/10.21460/gema.2016.11.217 
way of reading texts, interpreting by paying attention to changing contexts and perspectives, always suspending binary oppositions in the text so that the meaning of a text can never be stabilized and the hierarchy of a regime of meaning is shaken from within the text itself. From the results of reading the deconstruction will open a multi-perspective intertextual interpretation space. ${ }^{16}$

There are two stages in deconstruction: 1) Read the text word for word; 2) Transformation in new ideas. Deconstruction in this research is interpreted as a paradigm of correcting a normative essentialist interpretation and then finding a new paradigm in understanding the text. This will be done by re-questioning the results of the interpretation which is considered normative, then deconstructing it in a positive sense means rearranging a reading of the text that is more relevant.

Furthermore, in reconstructing the text, a sociological critical approach is used. Social criticism is used in interpreting texts. This method of interpretation sees the text itself as a practice of discourse that is loaded with ideological power and importance. Text is never pure or meaningless but always gives advocacy. In the text, there are two social groups and interests that are in conflict. ${ }^{17}$ When approached sociologically, the text itself is involved in the social struggle..$^{18}$

\section{Result and Discussion}

\section{Rereading the text of Exodus 20: 8-11 Using Deconstructive Method}

To explore the text in a literal way, transliteration of the original text and parsing will be carried out, then it will be translated verse by verse both literally and grammatically, following its interpretation and then deconstructing it based on the OT text in a wider context as a

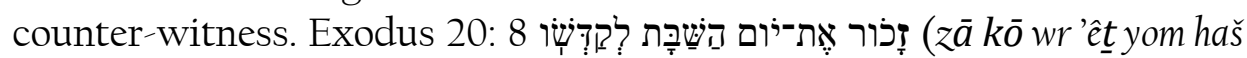

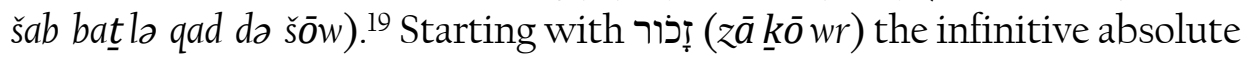
verb which is translated remember (NKJV), remember (RS). אֶּ ('êtyom)

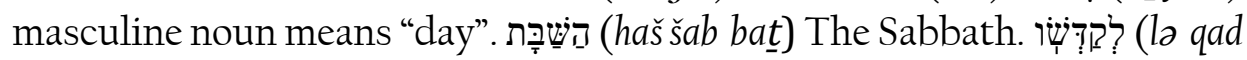
do šōw) לקִ begins with the preposition la followed by the third person infinitive piel form verb, translated to keep it holy (NKJV). The full

\footnotetext{
${ }^{16}$ F. Budi Hardiman, Seni Memahami. Hermeneutika Schleirmacher Sampai Derrida (Yogyakarta: Kanisius, 2015), 288-289.

${ }^{17}$ Walter Brueggemann, "The Book of Exodus," in The New Interpreter's Bible, ed. Leander E. Keck (Nashville: Abingdon Press, 1994), 681.

${ }^{18}$ Patrick D. Miller, ed., Old Theology Essays on Structure, Theme, and Text (Minneapolis: Fortress Press, 1992), 20-34.

19 “Exodus 20:8," Biblehub.com, https://biblehub.com/interlinear/exodus/20-8.htm
} 
translation of verse 8 from the original language text: "Remember and keep the Sabbath day holy."

Generally, nouns in Hebrew letters come from verbs. The word Sabbath comes from the verb form $2 a l$ which means to stop. The noun simply means a day of rest, which includes rest from work or daily routine activities. The word Sabbath has other nuances of meaning such as, rest, celebrate, or even implies fulfilment. Nonetheless, its basic meaning is rest. ${ }^{20}$ Etymologically, the word Sabbath comes from the verb "Sabbath" (to stop from something). There is a close connection between the Sabbath and the word "sheba" (seven) because of the strict 7-day rhythm.

In addition, there are striking similarities between The Sabbath with the Covenant word "syapattu". To some extent, this seven-day period was also known in Mesopotamia. However, the Mesopotamian Sabbath was different from the OT Sabbath, for the Babylonians they were not days of rest that had a celebratory character. but they were unlucky days. When examined in detail the pan-Babylonian theory of the origin of the Sabbath, it was clearly different from the Sabbath at the Pentateuch. 1) The special day of Babylon was observed not only on the 7th, 14th, and 14th day. 21, and 28, but on the 15th and 19th days; 2) In contrast to the 7 th day of the Bible which is found in clay tablets mentioning the 7th day as evil and unlucky day, day 7th in Genesis means it is a holy day; 3) The Babylonian Sabbath is for the great people, Kings, Prophets, and Physicians while the Jewish Sabbath is for everyone; 4) Activity continues in the Babylonian Sabbath in contrast to the Jewish Sabbath.

For the Israelites who had just come out of slavery, the Sabbath was a gift from Yahweh. The command is clear so that you remember and keep it holy. The Sabbath is also called a holy day because God blessed it (Gen. $2: 3$ ). The Sabbath is "holy" meaning it is set apart and different from other days. ${ }^{21}$

According to verse 8, the commandment "Remember and keep the Sabbath day holy," implies a prohibition to work or doing work on the Sabbath, so that it has the meaning contained in it a rest from all kinds of work or all routine daily activities, namely: "... six days you worked and did all your work." The above prohibition of work contains various nuances of the meaning of the word work or job, namely: business, livestock, handicrafts, work, duties, methods of work. The word "verb" from ọ example; service in general, job (never in the sense of being a slave) or

${ }^{20}$ T. Desmond Alexander, David W. Baker, Dictionary of the Old Testament:

Pentateuch (Westmont, Illinois: IVP Academic, 2002), 695.

${ }^{21}$ Volker Kesslerl, "The Sabbath as Remedy for Human Restlessness," In die Skriflig/In Luce Verbi 46, no. 2 (2012): 1-8, http://dx.doi.org/10.4102/ids.v46i2.61 
work, as well as property (as a result of labour) - business, livestock, work diligently, job, worker, work, working, creation. ${ }^{22}$

The translation of the entire verse 9 in the New King James Version: "but the seventh day is the Sabbath of the Lord your God. In it you shall do no work: you, nor your son, nor your daughter, nor your male servant, nor your female servant, nor your cattle, nor your stranger who is within your gates." For six days you will work and do all your work (v. 9), then according to the instructions in the next verse, the seventh day is the Sabbath of the Lord your God, so there is a prohibition to do any work that applies to the household, both humans and animals, which usually work stops to rest from their respective jobs (v. 10). The whole household and even livestock are also prohibited from working on the Sabbath, namely, "you or your son is a boy, or your child is a girl, or your servant is a girl, or your animal or a stranger." What should be noted here, in the sociology of the household of Israel includes male servants עַבְר (av de cha)

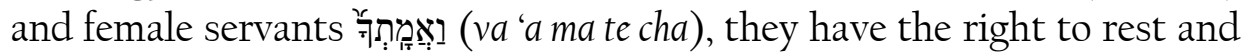
worship. The Sabbath prohibition has something to do with the prohibition of doing any manual work. The main basic idea of the Sabbath is a prohibition of work on that day and the Sabbath should be practiced regularly in a weekly cycle.

In verse 11 "... For in six days the Lord made the heavens and the earth, the sea, and all that is in them, and rested the seventh day. Therefore, the Lord blessed the Sabbath day and hallowed it." (NKJV). It is shown that there is a connection between the order of creation and the Sabbath. "... But the seventh day is the Sabbath of the Lord your God." In the event of creation the word Sabbath does not appear, but the root from which it was translated is there (Gen. 2: 2). The work of creation lasts 6 days; on the seventh day God rested (literally 'rested') from His work. Exodus 20:11 states that God rested on the seventh day, and Exodus 31:17 states that He quit His work and was 'refreshed'. After working in the work of creation for 6 days, Yahweh rested from the Hebrew word (way yō na) translated "He rested" (KJV), He stopped, literally means He did nothing, was silent, remained or quiet. ${ }^{23}$ God blessed the Sabbath day

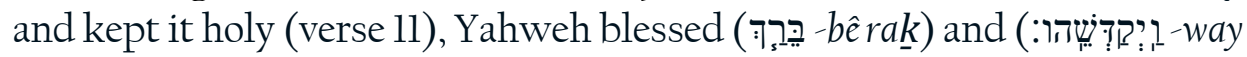

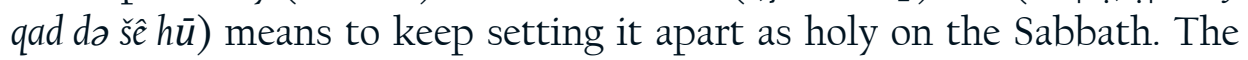
commandment to remember and keep the Sabbath holy is a commandment to rest. The LORD blessed the Sabbath day and kept it holy (v. 11).

${ }^{22}$ James Strong, Strong's New Exhaustive Concordance of the Bible (Madison: World Bible Publishers, Inc, 1992), 87.

${ }^{23}$ James Strong, Strong's New Exhaustive Concordance of the Bible, 87. 
The deconstruction of the text and the meaning of the Sabbath in the OT texts is shown by a verb that contrasts radically with the command "Remember and keep the Sabbath day holy." The Israelites in other OT texts forgot and polluted the Sabbath. This can be seen from the text of the testimony of the Prophets which is a direct warning to them (cf. Isaiah 58:13). In the full translation in the KJV translated version, you turn away your foot from the Sabbath from doing your pleasure on my holy day. The Israelites did not remember the Sabbath but instead turned and stepped away from the Sabbath. Not keeping the Sabbath day holy but turning away from the Sabbath to do one's own thing on the Holy Day of Yahweh. The people of Israel left the Sabbath day, which is Yahweh's Holy day, for true Israel, it is a delight, a glorious day. The Israelites did not honor the Sabbath by running many events, minding their own business, and speaking nonsense. In another verse, it is shown that Judah profaned the Sabbath by doing evil deeds.

In another place, it is stated that the worship and celebrations that the Israelites conducted were full of crimes, your celebrations were full of evil. Crime is used here the word (' $\bar{a} \cdot$ wen) means trouble of iniquity (KJV Isa. 1:13). The full translation of the verse: "If you celebrate the new moon and the Sabbath or have gatherings, I cannot bear to see them, because your celebrations are full of evil." In line with Isaiah, Ezekiel admonished, "... Thou hast despised the things that were holy to me and profaned my Sabbaths (Ezek. 22: 8). Not only the people but about the Priests it says, they turn a blind eye to My Sabbaths which means the same as defiling the name Yahweh among the people (Ezek. 22:26). The phrase

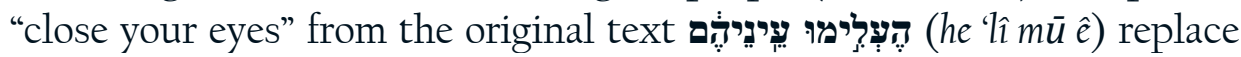
the plural masculine third person then translated "close their eyes". Several translated versions of he "î̀ mū ê nê hem, "and they shut their eyes" (NIV), "They disregard" (NLT), "they have hidden their eyes" (NKJV), "have hidden their eyes" (ASV), "they have disregarded" (RSV). The priests deliberately interpreted it as the opposite of what the Torah said, so they ignored the Sabbath; The priests have been unfaithful to be friends, the priests despise the Sabbath, do not view the Sabbath of Yahweh's holy day, in other words, they do not keep the Sabbath. ${ }^{24}$ In the grammatical research of the above text, the Sabbath is deconstructed its meaning.

However, the deconstruction of the Sabbath text has even confirmed its truth. The OT proves that it is not a legalistic religion that will ultimately succeed, but a religion of the heart, which means obedience to the Sabbath that comes from the heart. Next, there will be two stages in deconstructing. The first is reading the perspective of the enslaving

${ }^{24}$ F. Gardiner, "Ellicott's Commentary for English Readers," s.v. "Ezekiel 22," https://biblehub.com/commentaries/ellicott/ezekiel/22.htm 
Egyptians, the second reading from the perspective of global slavery of trafficking in persons.

The first, Deconstruction was carried out by reading the text from the perspective of the Egyptians who did not believe in Yahweh so that they did not embrace the concept of the Sabbath. Then the 4th commandment may be replaced imaginatively with the sentence: "By Pharaoh and his projects there is no Sabbath, seven days a week everyone is obliged to work by doing all your work. Do all the work whether you and your slaves, you and your sons, or your daughters, or your male servants, or your female servants, or your animals or strangers in your place of residence. Pharaoh is the ruler and therefore there is no Sabbath. "In the Exodus text, the central character is Pharaoh the slave oppressor and not Yahweh the slave savior. Pharaoh is the name of a dynasty (dynasty) that ruled Egypt for centuries which was historically the ruling dynasty in the Ancient Near East between 3000-63 BC. For a long time, the pharaohs were rulers in Egypt who were enslaved for 400 years. ${ }^{25}$ The nature and personality of the pharaoh are depicted in the narrative of Exodus in the time of Moses as a pharaoh who always orientates towards politics and economics. The orientation of power is indicated by political and domestic security considerations being the main consideration of the government as is the government in general. For political and domestic security reasons, slavery was planned with the intention of reducing the population of the Israelites so that they would not increase in number. The wealth-oriented nature of Pharaoh was shown by the building of the supply cities at Pitoom, and Ramses. However, even though the population of Israel was oppressed, it did not decrease so that forced labor was imposed even more hard on Israel (Exodus 1: 11-14). And this thing continued from time to time so that the Israelites were more and more oppressed, and the more violent they were with slavery.

In religion, power is characterized by elevating humans to become divine, exalting the pharaoh is equal to the divine. Pharaoh was considered divine as a god. ${ }^{26}$ The religious beliefs of the pharaoh exposed his personal character and his various political ambitions which received support from the priests in the temple who was also ambitious to have political power over the pharaoh, they revived the worship of the gods. Pharaoh was given spiritual dignity, described as being purely divine. Pharaohs followed the

25 Norman K. Gottwald, A Light to the Nations. An Introduction to the Old Testament (New York: Harper and Brothers, 1959), 68.

${ }^{26}$ Garry North, Authority and Dominion: An Economic Commentary on Exodus Part 1: Representation and Dominion (Dallas: Point Five Press, 2012), 2. 
custom of naming themselves after gods. ${ }^{27}$ All of these things were done to gain absolute power over the people.

Second, furthermore, the Sabbath deconstruction method is viewed from the perspective of modern slavery. The commandment for the sabbath is read in changing terms: Forget and ignore the Sabbath, seven days you will work and do all your work, for seven days is economic gain, Money is your master; Then do all your work for the sake of money for the benefit of your employer, you or your son, or your daughter, or your male servant, or your female servant, or your animal or foreigner in your residence. Because seven days is working for economic gain and there is no rest, money is first and foremost. What will be highlighted here is the modern slavery of trafficking which includes the process of moving, recruiting, transporting people by ship to ports by force, by force, and with the intention of being exploited. When they are far from their parents, they only live at the mercy of their master (master). Human trafficking is a process to a situation in which trafficked humans have no choice but to be exploited and trafficked and become slaves, it is even more pathetic to trade their organs. Human trafficking includes the recruitment, transportation, and transfer of a person from place A to place B. Get out of that system. ${ }^{28}$ So according to the facts, in a cultural system where money is number one, everything is done for the pursuit of financial gain, ${ }^{29}$ the employers have trafficked people, people are employed without rest.

From the results of the deconstruction of the text above, now the Sabbath will be reconstructed. To achieve the purpose of text interpretation Ex. 20: 8-11 which will be carried out with the paradigm of sociological criticism by still paying attention to coherence, narrative unity, and meaning in the Pentateuch in particular the whole book of Exodus. ${ }^{30}$

\section{Rereading the Sabbath from the Perspective of Sociological Criticism}

Sociological critical reading uses an interpretive paradigm that brings the meaning of output to the spirit of liberation by not contradicting a theocentric view of life, not as the antithesis of anthropocentric. Yahweh is still positioned as the Subject; however, the OT

${ }^{27}$ J. I. Packer, Merril C. Tenney. William White, Ensiklopedia Fakta Alktiab Bible Almanac-1 (Malang: Gandum Mas, 2003), 209, 2012-2130.

${ }^{28}$ Ella Syafputri, "Apa Itu Perbudakan Modern," Antaranews.com, November 18, 2014, https:/www.antaranews.com/berita/464938/apa-itu-perbudakan-modern

${ }^{29}$ Arie C. Leder, "The Coherence of Exodus Narrative Unity and Meaning," Calvin Theological Journal 36 (2001): 251-269.

${ }^{30}$ Norman K. Gottwald, A Light to the Nations. An Introduction to the Old Testament (New York: Harper and Brothers, 1959), 4-5. 
is a story about humans that are horizontal. The OT God has entered life with humans actively. With a sociological perspective in viewing the OT consists of two dimensions; a vertical dimension which affirms divinity and a horizontal dimension which affirms activity in this world. By finding God or rather being found by God, then man will find himself. The reading with the social criticism model succeeds in proving the relevance of the OT in today's social life. Yahweh is involved in social struggles and justice includes the management of the world according to His means and purposes.

The Yahweh described in the testimony of Israel is God in relation to Israel, the human person, the nation, and creation as its partner. God, who is declared sovereign but is also present amid the struggles of man and creation. By describing a verb that is transformative, we can find an understanding of God as the victorious savior, the deliverer of his people, who rules his people by giving commands to be obeyed. If God's will be obeyed, it will present shalom during the nation even though they must face the dominant counterculture. OT from a sociological perspective state that in social life, it protects the weak from oppression and greed and invites members of society to be responsible for each other, namely by implementing a culture of sabbath that humanizes humans, liberates human society from consumptive, exploitative, and repressive acts as pharaoh does. ${ }^{31}$

Reading the text will inspire about Yahweh as the initiator who legitimizes liberation throughout the ages to the liberation of people who are enslaved throughout the ages. Exemption of children who have been trafficked or children who have been sold by their parents to pay off debts. Or the exemption of people who work past hours, who are unpaid or underpaid.

\section{God of the Sabbath as the Pioneer of Slavery Liberation}

God cares for every individual who experiences suffering. To describe God's liberating work, Exodus uses several transformational verbs such as Yahweh bring out, Yahweh is the agent who approves of, and encourages, and executes Israel's departure (Exodus 13:3; cf. 12:41; 14:8). God's deliverance refers to the Exodus narrative in which Israel saved God from the dangers of slavery in Egypt through vigorous action (Exodus 3:8; cf. 5:23; 6:6; 18:9). God redeems, meaning a transformative act. Yahweh acted as a family member to redeem family members with the intention of preserving and maintaining the family's welfare (Exodus 6:5 cf. 15:13). Yahweh was liberated, indicating God's mighty acts, which

${ }^{31}$ Walter Bruggemann, Sabbath as Resistance: Saying No to The Culture of Now (Louisville, Kentucky: Westminster John Knox Press, 2014), 5. 
ended situations of fear, suffering, and helplessness and created the possibility of a counterculture life which Israel accepted with joy (Exodus 14:13). God redeems, which means transactional where a person is freed from a difficult situation economically by paying a ransom (Exodus 13:15). Yahweh brought up, that is, Yahweh moved Israel from a lower place to a higher place, from the status of slaves to the status of free people, from Egypt to the promised land. In other words, Yahweh lifted and raised Israel — changed her situation for the better (Exodus 3: 8, 3:17).

Retelling through the narrative of the Exodus, God repeatedly and reliably carries out transformations throughout Israel's formative memory. It is true that the warning of the Exodus remains intact for the outward confirmation of Israel's existence, but it turns out that later the exclusivity of Israel as an exodus nation and Yahweh as God of the exodus was broken because it turned out that God had led Israel from Egypt to do the same for the nations (cf. Amos 9: 7). Israel is not allowed to have claimed an exclusive claim to Yahweh. Yahweh as the subject of transformative verbs is the actor of social reform inclusively and in a universal way. The transformative liberated emancipation act carried out by God can occur and be carried out in all places and in different situations outside of Israel, in other words, it is inclusive. The right to freedom and freedom from slavery belongs to all people in all nations. Normative theological discourse in understanding justice includes the management of the world in accordance with God's aims and objectives. God was in constant relationship with Israel, the human person, the nations, and creation as its partner. God is declared to be sovereign, at the same time being present amidst the struggles of man and creation.

\section{God's Community with a Liberative Mission}

The Gods community that celebrates the Sabbath accepts moral responsibility with a mission of liberation. Metaphorically, the God community is "Moses" of today as a mediating agent to bring a message to the "Pharaohs" of today to release their enslaved people. Like Moses in the Exodus text is not as a central actor, but as an instrument in the hand of God, only sent with the mandate of liberation.

In the OT perspective, the world was a stage for God's activity. The mission is God's love and cares directed primarily to the world, and the mission is the participation of God's existence in the world. In the missionary involvement of the church regarding the realities of injustice, oppression, poverty, discrimination, and violence. And even so, the church is involved in the social-political fact. But does not mix with social and political movements so that it is thoroughly identified with it.

Furthermore, seen from the perspective of the Old Testament, the meaning of mission can be seen from the understanding of the Israelites 
who believe that history is an arena for God's activities, the focus is on God who has been, is, and is still doing, according to His will. The OT Yahweh is God in action; the OT narrative portrays God's repeated acts' repetitive, transforming narrative. The OT Yahweh is a covenant God who is active in history and becomes a future. ${ }^{32}$ God gives transformational hope. God has chosen His people for service.

\section{Conclusion}

The Sabbath is a day of rest. Rest from all work for all, all workers and even a stop to assist work such as animals. The purpose of rest is to remember the Creator by worshipping God's redemptive work, which frees a nation from slavery. The principle adopted by discovering the meaning of the Sabbath, all forms of slavery are ended, and a humane working day is promoted where there is time to rest. Work is not by force but as a service for the good of the worker and his fellowmen.

In rereading by deconstructive methods, the Sabbath was abandoned, forgotten, and profaned. The text's deconstructive reading of the Egyptian perspective was found due to political and economic power factors, and the Sabbath was eliminated in Egypt. Everyone was obliged to work by force every day, and there were no rest days; the slaves were forced to work without stopping. Furthermore, from a deconstruction reading in the perspective of modern slavery, it is found that the Sabbath was eliminated because money was first and foremost. The greed for money caused a sacrifice of human rights. Every day people must be employed continuously without stopping. Work is interpreted as forced labour and slavery. Every day people work motivated for money and are inspired by greed.

And then rereading of the Sabbath from a sociological perspective result in a theological interpretation. God the Sabbath frees people from slavery. God frees the world from all lusts for political power, economic power, and greed for money. God delivered people from the bondage of slavery. God assigns His people to be an active agent of deliverance to the people from modern slavery of human trafficking.

32 David J. Bosch, Transformasi Misi Kristen: Sejarah Teologi Misi Yang Mengubah Dan Berubah (Jakarta: BPK Gunung Mulia, 2012), 23-26. 


\section{Bibliography}

Alexander, T. D., David W. Baker. Dictionary of the Old Testament: Pentateuch. Westmont, Illinois: IVP Academic, 2002.

Barclay, John M. G. "Am I not a Man and a brother? The Bible and the British Anti-Slavery Campaign.” The Expository Times 119, no. 1 (2007): 3-14.

Blevins, Kent. "Observing Sabbath." Review and Expositor 113, no. 4 (2016): 478-487.

Bosch, David J. Transformasi Misi Kristen: Sejarah Teologi Misi Yang Mengubah Dan Berubah. Jakarta: BPK Gunung Mulia, 2012.

Brueggemann, W. "The Book of Exodus.” In The New Interpreter's Bible, ed. Leander E. Keck Nashville: Abingdon Press, 1994.

Bruggemann, Walter. Sabbath as Resistance: Saying No to The Culture of Now. Louisville, Kentucky: Westminster John Knox Press, 2014.

Christ, K. L., K. K. Rao and R. L. Burritt. "Accounting for modern slavery: an analysis of Australian listed company disclosures." Accounting, Auditing e Accountability Journal 32, no. 3 (2019): 836-865.

Clines, David J. "Images of Yahweh: God in the Pentateukh." In Studies in Old Testament Theology, ed. Robert L. Hubbart, Robert K. Johnston, Robert P. Meye. Dallas: Word Publishing, 1992.

"Exodus 20:8." Biblehub.com. https://biblehub.com/interlinear/exodus/208.htm

Frey, Mathilde. "The Sabbath in the Pentateuch: An Exegetical and Theological Study." Dissertations Ph.D., Andrew University Seventh-day Adventist Theological Seminary, 2011. https://digitalcommons.andrews.edu/dissertations/51

Gardiner, F. "Ellicott's Commentary for English Readers." https://biblehub.com/commentaries/ellicott/ezekiel/22.htm

Gottwald, Norman K. A Light to the Nations. An Introduction to the Old Testament. New York: Harper and Brothers, 1959.

Haas, G. H. "Slave, Slavery.” In Dictionary Old Testament: Pentateuch, ed. T. Desmond Alexander, David W. Baker. Downers Grove, IL InterVarsity Press, 2003.

Hardiman, F. Budi. Seni Memahami. Hermeneutika Schleirmacher Sampai Derrida. Yogyakarta: Kanisius, 2015.

Johnson, Sylvester A. "The Bible, Slavery, and the Problem of Authority," in Beyond Slavery. Black Religion/Woman Thought/Social Justice. New York: Palgrave Macmillan, 2010. https://doi.org/10.1057/9780230113893_4 
Kesslerl, V. "The Sabbath as Remedy for Human Restlessness." In die Skriflig/In Luce Verbi 46, no. 2 (2012): 1-8.

http://dx.doi.org/10.4102/ids.v46i2.61

Leder, Arie C. "The Coherence of Exodus Narrative Unity and Meaning." Calvin Theological Journal 36 (2001): 251-269.

Manoe, Herman A. "Resensi: Menolak Diam-Gereja Menolak Perdagangan Orang.” Gema Teologika: Jurnal Teologi Kontekstual dan Filsafat Keilahian 4, no. 1 (2019): 121-124. https://doi.org/10.21460/gema.2019.41.425

Miller, Patrick D., ed. Old Theology Essays on Structure, Theme, and Text. Minneapolis: Fortress Press, 1992.

North, Garry. Authority and Dominion: An Economic Commentary on Exodus Part 1: Representation and Dominion. Dallas: Point Five Press, 2012.

Packer, J. I. Merril C. Tenney. William White. Ensiklopedia Fakta Alktiab Bible Almanac-1. Malang: Gandum Mas, 2003.

Palmiotto, Michael J. "Introduction: Human trafficking-modern slavery." In Combating Human Trafficking a Multidisciplinary Approach. Edited by Michael J. Palmiotto. United states: CRC Press 2015.

Pelt, Miles V. Van, Gary D. Pratico. The Vocabulary Guide to Biblical Hebrew. Grand Rapids, Michigan: Zondervan, 2003.

Singgih, Emanuel Gerrit. "Membaca Dan Menafsir Alkitab Di Indonesia."

Dalam Teologi Yang Membebaskan Dan Membebaskan Teologi." Ed.

Wahju S. Wibowo, Robert Setio. Yogyakarta: Fakultas Teologi UKDW, 2016.

Singgih, Emanuel Gerrit. "Resensi: Sebuah Teologi Perjanjian Lama Postmodernis." Gema Teologika: Jurnal Teologi Kontekstual dan Filsafat Keilahian 1, no. 1 (2016): 117-118. https://oi.org/10.21460/gema.2016.11.217

Slavery Today, "What is modern slavery." https:/www.antislavery.org/slavery-today/modern-slavery/

Stringer, C., D. H. Whittaker, and G. Simmons. "New Zealand's turbulent waters: the use of forced labour in the fishing industry." Global Networks 16, no. 1, (2016): 3-24.

Strong, James. Strong's New Exhaustive Concordance of the Bible. Madison: World Bible Publishers, Inc, 1992.

Syafputri, Ella. "Apa Itu Perbudakan Modern." Antaranews.com, November 18, 2014. https://www.antaranews.com/berita/464938/apa-ituperbudakan-modern.

The Global Slavery Index, "Executive Summary." Walk Free Foundation, 2018. https://www.globalslaveryindex.org/2018/findings/executivesummary/ 